\title{
As negociações comerciais entre Mercosul e União Européia
}

\author{
MARCOS SAVINI*
}

\section{Introdução}

Após o difícil lançamento de negociações sobre uma futura associação biregional entre o Mercosul e a União Européia, durante a Cimeira da América Latina, Caribe e UE, realizada no Rio de Janeiro em junho e julho de 1999, a afirmação de que elas serão "longas e difíceis" tornou-se uma cantilena nas chancelarias. Mas uma nota dissonante foi aparentemente emitida no início de julho de 2001, por ocasião da quinta reunião do Comitê de Negociações, realizada em Montevidéu, quando os representantes europeus apresentaram um conjunto de propostas de redução de barreiras tarifárias hoje aplicadas às exportações dos países do Mercosul.

À primeira vista, a União Européia passou a adotar uma postura mais ativa, demonstrando o claro desejo de fazer as negociações avançarem. Paralisados por uma nova crise em sua aliança regional, aberta pelas declarações do ministro argentino Domingo Cavallo contrárias à Tarifa Externa Comum (TEC) e à política de taxas de câmbio flutuantes no Brasil, os países do Mercosul encontraram-se incapacitados de apresentar sua própria oferta. ${ }^{1}$

A iniciativa européia surpreendeu e, embora não satisfaça plenamente às expectativas de empresários e negociadores brasileiros, notadamente na questão dos subsídios oferecidos pela UE a seus agricultores, tem sido interpretada como um importante gesto político, uma prova de real interesse em estabelecer um acordo de liberalização comercial com o Mercosul. ${ }^{2}$ Ao mesmo tempo, denota a preocupação da Comissão Européia em manter tais negociações emparelhadas, ou até mesmo à frente, ao processo de criação de uma Área de Livre Comércio das Américas (Alca), com data de lançamento marcada para o dia $1^{\circ}$ de janeiro de 2006.

A estratégia da Comissão reflete o óbvio receio europeu em ver sua predominância junto aos mercados dos países do Mercosul minguar caso a Alca um dia torne-se uma realidade. Juntos, os 15 países da União Européia foram responsáveis por cerca de 28\% das importações brasileiras em 1999. ${ }^{3}$ É o principal 
parceiro comercial do Brasil. Os Estados Unidos vêm a seguir, com 23\% das importações, também segundo dados de 1999. A União Européia é também o maior investidor estrangeiro no Mercosul, com um estoque de 80,3 bilhões de euros em 1999. Suas empresas são responsáveis por cerca de 50\% do capital externo presente no setor produtivo argentino e cerca de $40 \%$ no brasileiro. ${ }^{4}$

Entre os funcionários da Comissão Européia encarregados pelas negociações com o Mercosul, a necessidade constante de manter ao menos uma paridade com o processo de avanço da Alca explica-se pelo receio de uma repetição do caso mexicano, que ao longo da década de 90 teve praticamente todo seu antigo comércio com os países europeus desviado para os EUA, em especial depois de sua adesão ao Nafta (Área de Livre Comércio da América do Norte) em 1993. Tal preocupação foi expressa claramente, por exemplo, às vésperas da uma visita realizada por Chris Patten, comissário das Relações Exteriores da Comissão Européia, ao Brasil em novembro de 2000: "Temos um interesse enorme em fechar esse acordo com o Mercosul, para não perdermos espaço para os Estados Unidos, como aconteceu no México". 5

A mesma lógica vale para as negociações que a União Européia mantém com o Chile. Mal fora anunciada a possibilidade deste país aderir ao Nafta para que a Comissão Européia, por sua vez, viesse a admitir o desejo de assinar um acordo de livre comércio com os chilenos durante a segunda Cimeira da América Latina, Caribe e União Européia, que será realizada em maio de 2002, em Madri. ${ }^{6}$

Uma rápida retrospectiva sobre o processo de criação da Alca e da proposta de conclusão de um acordo bi-regional com o Mercosul é suficiente para demonstrar como cada passo dado do outro lado do Atlântico é seguido com atenção pela Comissão Européia em Bruxelas.

\section{À procura de um acordo bi-regional: dos anos 80 a nossos dias}

Ao final da década de 80, a crise da dívida externa, a agonia do modelo de confrontação bipolar entre Estados Unidos e União Soviética no cenário político mundial e a crescente globalização econômica criam um contexto favorável à reorientação do modelo de desenvolvimento nacionalista e autárquico adotado pela maioria dos países latino-americanos até então. Abertura comercial, busca de maior integração regional e distanciamento de antigas políticas terceiro-mundistas marcam a virada dos anos 80 para os 90 no subcontinente. A política externa passa a privilegiar os contatos com as nações industrializadas e com os países vizinhos, ao invés de explorar alianças estratégias nas brechas da Guerra Fria entre as duas superpotências. Os objetivos são econômicos: melhoria da competitividade, conquista dos mercados de exportação e reforço da capacidade de negociação comercial com os países desenvolvidos. ${ }^{7}$ 
Diversas iniciativas e processos de integração regional tiram partido deste contexto favorável. Em 1987, os países-membros da então chamada Comunidade Econômica Européia (CEE) haviam firmado o Ato Único Europeu, pelo qual decidiram a criação de um mercado comum sobre as bases de sua união aduaneira. Às antigas motivações políticas, de garantia da paz e da estabilidade no continente, ele atende à necessidade de melhorar as condições de competitividade das empresas européias frente à concorrência japonesa e norte-americana no mercado mundial. No ano seguinte, Estados Unidos e Canadá criam a Área de Livre Comércio da América do Norte (Nafta).

No Cone Sul, o processo de integração tem início em 1988, quando os presidentes do Brasil e da Argentina, José Sarney e Raul Alfonsín, assinam a Ata de Buenos Aires. O marco fundamental do Mercosul acontece em março de 1991, com a assinatura do Tratado de Assunção, por Argentina, Brasil, Paraguai e Uruguai. Ao prever a criação de uma união aduaneira entre esses países, a partir de $1^{\circ} \mathrm{de}$ janeiro de 1995, ele estabelece um pólo de integração sul-americano alternativo ao Nafta.

A partir de então, o Mercosul torna-se o eixo estratégico da política externa brasileira para a promoção de melhores fluxos de comércio, da atração de investimentos, do equilíbrio entre seus vários parceiros comerciais. Unido a seus vizinhos, o Brasil passaria a contar com uma melhor plataforma para o lançamento de negociações comerciais multilaterais ou inter-regionais, garantindo assim seu desenvolvimento econômico independente e equilibrado em relação às grandes potências comerciais, em especial aos Estados Unidos. ${ }^{8}$ Tal estratégia, batizada de "regionalismo aberto", aliada à abertura comercial unilateral iniciada no governo de Fernando Collor (1990), estabelece uma ruptura em relação ao modelo autárquico, baseada na substituição de importações, seguida pelo país ao longo de quatro décadas.

Menos de um mês após a assinatura do Tratado de Assunção, os chanceleres do Mercosul reúnem-se com o presidente da Comissão Européia em Luxemburgo para lançar a idéia de um acordo de cooperação institucional. Tratavase, em última análise, da afirmação do bloco sul-americano no cenário internacional. O Acordo de Cooperação Interinstitucional Mercosul/UE concretiza-se em maio de 1992, prevendo colaboração nas áreas de aduanas, normas técnicas e agricultura.

Com a adesão do México ao Nafta em 1993, a idéia de ampliar as negociações com o Mercosul ganha força na Comissão Européia, o que é discutido em uma reunião de ministros das Relações Exteriores realizada em abril de 1994, em São Paulo. Dois meses depois, na cúpula de Corfu, a Comissão apresenta ao Conselho Europeu um comunicado que afirma ser o fortalecimento das relações com o Mercosul, inclusive comerciais, estratégico para a UE. Em novembro, uma nova reunião de chanceleres com as autoridades da Comissão é realizada para decidir, em Bruxelas, os próximos passos do aprofundamento da relação entre os 
dois blocos.

Em dezembro de 1994 todos os processos de integração envolvendo o Brasil entram em rota de confluência. No plano regional, o Mercosul ganha personalidade jurídica com a assinatura do Protocolo de Ouro Preto, que abre caminho para a conclusão de acordos abrangentes com países ou grupos terceiros. No plano hemisférico, o presidente Bill Clinton recebe os líderes de outros 33 países para lançar, na Cúpula de Miami, o projeto de uma Área de Livre Comércio das Américas (Alca), proposta inicialmente formulada pelo governo de George Bush ("Iniciativa para as Américas"). Sob insistência brasileira, é aceito o princípio de que a integração acontecerá por um processo de convergência dos blocos econômicos já existentes ("building blocs") e não por adesões individuais ao Nafta.

No plano bi-regional, Mercosul e União Européia divulgam declaração conjunta anunciando uma "estratégia cujo objetivo final seja a associação política e econômica inter-regional", prevendo "a liberalização progressiva e recíproca de todo o comércio, tendo em conta a sensibilidade de alguns produtos e de acordo com as normas da OMC”. Em janeiro, a Comissão Européia começa a preparar um projeto de negociação de um Acordo-Quadro com o Mercosul, que recebe o Chile como país associado e dá início à união aduaneira prevista no Tratado de Assunção.

Reunidos em Paris, em maio de 1995, os chanceleres do Mercosul e da União Européia anunciam a intenção de assinar o acordo-quadro no segundo semestre de 1995. O mandato autorizando a Comissão a negociá-lo é aprovado pelo Conselho Europeu em junho e, após duas reuniões de negociações, o texto é concluído em setembro. Enquanto isso, a Alca avança com a formação em junho, na reunião de Denver, dos grupos de trabalho da Alca - acesso a mercados, procedimentos aduaneiros, regras de origem, investimentos, medidas fitosanitárias, subsídios e defesa comercial.

A assinatura do acordo-quadro entre a União Européia e o Mercosul acontece em Madri, no dia 15 de dezembro de 1995. Ele estabelece os objetivos de fortalecer as relações recíprocas e preparar as condições para a criação de uma associação inter-regional de cunho político e econômico. Estabelece ainda um quadro institucional para um diálogo regular e sistemático, composto de um Conselho de Cooperação, formado por ministros; uma Comissão Mista de Cooperação (grupo técnico responsável pela formulação de propostas), e uma Sub-comissão Comercial.

A assinatura do Acordo-Quadro é cercada pela expectativa de se chegar a uma conclusão a médio prazo. Entretanto, nem datas nem prazos foram fixados, por duas razões. Primeiro, pela "cautela" do governo brasileiro em não se aventurar em uma zona de livre comércio entre grupos com níveis desiguais de desenvolvimento econômico, levando ainda em conta a recente e traumática experiência da abertura comercial unilateral do início dos anos 90. Segundo, por conta das outras prioridades dos dois blocos. 
No caso do Mercosul, a consolidação de sua união aduaneira, o aprofundamento de sua harmonização macroeconômica - o que só viria a acontecer depois da crise da desvalorização do real em 1999 -, a ampliação geográfica em direção à uma Área de Livre Comércio da América do Sul (Alcsa) e as negociações da Alca. ${ }^{9}$

A União Européia, por sua vez, encontrava-se imersa nos trabalhos de implementação de sua União Econômica e Monetária (o euro), de ampliação geográfica em direção aos países do Leste Europeu, de reforma do orçamento e da política agrícola comum (PAC), e de aprofundamento de suas relações extracontinentais - onde o Mercosul é apenas um dos atores, ao lado dos países Mediterrâneos, África do Sul (com quem a UE assinaria um acordo de livre comércio em março de 1999), México (março de 2000) e uma nova Convenção de Lomé (maio de 2000) para suas ex-colônias na África e Caribe.

O relativo marasmo viria a ser quebrado pelo avanço das negociações da Alca. Em maio de 1996, na reunião ministerial de Belo Horizonte, é dado o início ao processo negociador da zona hemisférica de livre comércio, com a definição de sua data de conclusão, 2005, e da metodologia das negociações. Por insistência da delegação brasileira, dois princípios são consagrados: todas as decisões terão de ser tomadas por consenso e todas as negociações setoriais devem ser discutidas e concluídas ao mesmo tempo ("single undertaking").

No mês seguinte, em Luxemburgo e Bruxelas, durante o primeiro encontro de chanceleres e da Comissão Mista UE/Mercosul, define-se o papel e a composição da Subcomissão Comercial. Ela será responsável pelo trabalho de preparar as negociações e terá três grupos de trabalho (bens, serviços e normas e disciplinas comerciais). Reunida pela primeira vez em novembro de 1996, em Belo Horizonte, ela estabelece três etapas para o processo negociador. Primeiro, a elaboração das chamadas "fotografias" sobre o comércio bi-regional. Segundo, análises internas e identificação de produtos prioritários e sensíveis de cada país. Terceiro, definição de estruturas de trabalho sobre a liberalização comercial.

A partir de então, o tema agrícola começa a despontar claramente como o grande nó das negociações bi-regionais. O primeiro sinal foi emitido em junho de 1997, durante a segunda reunião da Subcomissão Comercial em Bruxelas, quando ela decide retirar dos Grupos de Trabalho a tarefa de identificar produtos prioritários e sensíveis, por considerar que este é um trabalho político e não técnico. Em março de 1998, um grupo ad-hoc do Mercosul reunido em Buenos Aires acrescenta o debate sobre a política agrícola comum (PAC) praticada pela União Européia aos documentos de trabalho da Subcomissão Comercial.

Em julho de 1998 a Comissão Européia, sob uma iniciativa de seu vicepresidente, o espanhol Manuel Marín, formaliza junto ao Conselho Europeu um pedido para negociar com o Mercosul um acordo prevendo a cooperação política e econômica, incluindo a formação de uma área de livre comércio. A discussão 
entre os ministros de agricultura dos 15 países-membros foi ardorosa. $\mathrm{O}$ representante francês, Louis Le Pensec argumentou que um acordo com os países do Mercosul acarretaria um custo adicional de 9 bilhões de euros à PAC, para manter os preços pagos aos fazendeiros franceses nos níveis mínimos praticados naquele momento. "O que está em jogo é a nossa habilidade de definir e defender um certo conceito de agricultura", ponderou Pensec naquela ocasião. ${ }^{10}$

O pedido de um mandato negociador por parte da Comissão Européia sofre, portanto, a oposição de diversos países - França, Alemanha, Bélgica, Luxemburgo, Portugal, Grécia e Áustria -, que pedem uma revisão da proposta, após a realização de novos estudos sobre que tipo de prejuízos seus produtores agrícolas poderiam sofrer frente a uma futura livre competição com o Mercosul. Mais favoráveis ao projeto, ou aos princípios de livre comércio, apenas a Espanha, a Suécia e a Finlândia. O Reino Unido, por sua vez, argumenta a favor de negociações multilaterais amplas na Organização Mundial do Comércio, levando a delegação francesa a exigir que as questões comerciais fossem tratadas com o Mercosul apenas em 2003, quando, supunha-se, teria terminado a "Rodada do Milênio" da OMC. Ambos países opunham-se à menção explícita a uma "área de livre comércio". ${ }^{11}$

O otimismo em relação à associação inter-regional arrefece principalmente após a conclusão dos trabalhos de "fotografia" do comércio entre os dois blocos. Segundo o artigo XXIV do GATT, uma área de livre comércio só pode ser assim denominada se as barreiras ao comércio "forem eliminadas substancialmente para todo o comércio" entre as partes do acordo. Tal afirmação tem sido traduzida como algo em torno de $85 \%$ a $90 \%$ do intercâmbio comercial. Oras, o levantamento realizado pela Comissão Européia ao longo de 1998 detectou que 14\% dos produtos europeus poderiam ser considerados "sensíveis", e que o custo adicional para PAC poderia chegar a 14 bilhões de euros ao ano.

A partir de então, acreditando que seus setores agrícolas serão prejudicados por um acordo de livre comércio com o Mercosul, alguns países europeus, liderados pela França, passam a emperrar o processo de negociação. As negociações tornaram-se difíceis, e não apenas por conta das dificuldades dos países-membros da União Européia em encontrar um consenso sobre um acordo com o Mercosul.

A crise interna do bloco sul-americano, iniciada com a desvalorização do real (janeiro de 1999), o fracasso do lançamento da Rodada do Milênio da OMC em Seattle (dezembro de 1999) também tornaram o cenário das negociações mais incerto. Uma dificuldade adicional é o processo de ampliação da UE para os países do Leste Europeu. Desde que passaram a receber 520 milhões de euros ao ano para investimentos na agricultura e no desenvolvimento rural, esses candidatos à adesão tornaram-se potenciais votos favoráveis à manutenção da Política Agrícola Comum (PAC) - identificada pelos países do Mercosul como maior obstáculo para a conclusão de um acordo bi-regional. 
A decisão de aprovar um mandato autorizando a Comissão Européia a negociar com o Mercosul, que a princípio seria tomada a nível ministerial pelo Conselho Europeu, é repassada em maio de 1999 para a reunião da cúpula européia de Colônia de junho de 1999. Enquanto isso, em Santiago do Chile, os chanceleres da Argentina, Brasil e Chile alertam que a Cimeira da América Latina, Caribe e União Européia, marcada para o final também de junho, no Rio de Janeiro, resultará em fracasso caso os europeus não aprovem o mandato negociador.

Presente no rascunho do documento final da cúpula de Colônia, a aprovação do mandato é retirada na última hora. A decisão será tomada, finalmente, apenas uma semana antes da Cimeira do Rio de Janeiro, no dia 21 de junho. Mas com a condição de que as negociações sobre barreiras tarifárias sejam iniciadas apenas em julho de 2001 .

No dia primeiro de julho, a Declaração Conjunta Mercosul/UE é aprovada às margens da Cimeira do Rio. Ela prevê o início de negociações em novembro de 1999. Por insistência européia, ela não menciona nem data de conclusão (ao contraste com a Alca) nem a expressão, "área de livre comércio", substituída por "liberalização progressiva". Estabelece ainda que as negociações da União Européia com o Mercosul e com o Chile acontecerão em separado.

Por ocasião da reunião de lançamento da negociações, realizada em Bruxelas em novembro de 1999, as duas partes não chegam a um acordo sobre a data do início das discussões sobre barreiras tarifárias. Por outro lado, estabelecem o cronograma e a estrutura das conversações: um Comitê de Negociações Biregional (com três reuniões anuais), Subcomitê de Cooperação (ao menos uma reunião anual), Grupos de Trabalho (reuniões paralelas ao do Comitê) e secretariados.

Em fevereiro de 2000, uma reunião de chanceleres em Vilamoura (Portugal), dá um novo alento político às negociações. Por outro lado, a presidência portuguesa do Conselho Europeu defende a inclusão de temas ambientais e trabalhistas nas discussões. Dois meses mais tarde, durante o primeiro encontro do Comitê de Negociações, em Buenos Aires, são definidos os grupos de trabalho. $\mathrm{O}$ primeiro será encarregado de bens, acesso a mercados (incluindo normas fitosanitárias), procedimentos alfandegários, licenças de importação, regras de origem e controle de qualidade. O segundo tratará de investimentos, serviços, fluxos de capital, propriedade intelectual e patentes. $O$ terceiro, de competição e resolução de conflitos. ${ }^{12}$

\section{O momento das negociações tarifárias}

Temas não-tarifários e o acerto de detalhes nos textos das negociações foram os assuntos predominantes nas três reuniões seguintes do Comitê de Negociações: Bruxelas (junho de 2000), Brasília (novembro de 2000) e novamente 
Bruxelas (março de 2001). Porém, essa monotonia inerente aos trabalhos técnicos foi quebrada com a apresentação da proposta de redução tarifária apresentada pela Comissão Européia em Montevidéu. Nas palavras espirituosas do embaixador José Alfredo Graça Lima, subsecretário de Assuntos Econômicos, Comerciais e de Integração do Ministério das Relações Exteriores, por ocasião da quarta reunião do Comitê de Negociações, em Bruxelas, a oferta européia equivaleria ao momento em que "o pudim está na mesa e temos condições de prová-lo". ${ }^{13}$

A aparente renovação do entusiasmo europeu pelas negociações com o Mercosul surpreendeu o empresariado brasileiro, até então com suas atenções voltadas principalmente para o processo de criação da Alca. Hoje, já se admite que talvez será mais fácil negociar com os europeus. ${ }^{14}$

Outro importante elemento facilitador para o desenrolar das negociações com a União Européia é o fato dela não ter de enfrentar a antipatia da opinião pública ou mesmo de certos setores do empresariado, como acontece no caso da Alca. Ao contrário desta última, elas jamais foram alvo de protestos por parte da sociedade civil organizada, como os que marcaram a quarta reunião de cúpula da Alca, no Quebec, em abril de 2001. No mês seguinte ao encontro, o embaixador José Alfredo Graça Lima admitia que "no Brasil, a opinião pública tende a ver a Alca como risco, e não como oportunidade". ${ }^{15}$

Difícil é saber se tal fato acarreta uma vantagem, ou não, para a conclusão de uma aliança bi-regional com a União Européia. Aparentemente, esta quase inexistência de oposição interna ao projeto de um acordo entre Mercosul e UE facilita o trabalho das equipes encarregadas tanto dos aspectos técnicos como políticos das negociações. Por outro lado, pode também ser interpretada como desinteresse da opinião pública ou despreparo do empresariado na tarefa de identificar oportunidades e perigos a serem levados em conta nas negociações. Este descompasso dos setores empresariais em relação às negociações com a União Européia vem sendo compensado nos últimos meses, certamente por causa da inesperada rapidez com que a Comissão Européia apresentou sua proposta na reunião de Montevidéu. ${ }^{16}$

Uma avaliação mais objetiva sobre as vantagens comparativas entre as distintas negociações, União Européia ou Alca, é hoje ainda difícil, frente à falta de estudos abrangentes sobre os impactos que cada uma delas teria sobre a economia brasileira. A exceção é o levantamento realizado pela Fundação Getúlio Vargas (FGV), encomendado em 1998 pelo Ministério do Desenvolvimento, Indústria e Comércio Exterior. Ele aponta, a princípio, para uma preferência pelo acordo biregional com a UE, pelos ganhos que o mesmo provocaria para as exportações de produtos agropecuários. Porém, não deixa de mencionar que a indústria brasileira de manufaturados seria mais beneficiada pela Alca, uma vez que ela tem nos Estados Unidos seu principal destino. ${ }^{17}$ 
De todo modo, este ambiente favorável, ou pelo menos não hostil, explicaria porque as negociações com a União Européia, embora iniciadas apenas em 1999, teriam passado à frente às da Alca. Enquanto a discussão hemisférica abordará questões cruciais, como acesso a mercado e desgravação tarifária, somente a partir de maio de 2002, esses mesmos temas começaram a ser tratados pelos blocos sul-americano e europeu já a partir de julho de 2001, quando a Comissão Européia apresentou sua primeira oferta.

Entretanto, apesar de todos os argumentos positivos acima apontados, indicando aparente vantagem a favor da União Européia nesta suposta corrida por acesso ou manutenção de mercados latino-americanos, essa conclusão parecenos pouco sustentável quando confrontada, primeiro, às realidades internas da UE $\mathrm{e}$, segundo, ao contexto multilateral.

É praticamente inconcebível que a Política Agrícola Comum (PAC) venha a ser desmantelada apenas para favorecer as importações de produtos agropecuários oriundo do Mercosul. Ao se tomar como exemplo a última reforma da PAC, realizada no Conselho Europeu de Berlim, em março de 1999, constata-se como o debate interno sobre a questão concentra-se, sobretudo, em fatores orçamentários. ${ }^{18}$ Em outras palavras, discutiu-se quem continuará a pagar a conta, em especial no caso dela engordar quando soar a hora dos 12 países candidatos, na Europa Central e do Leste, à adesão à União Européia.

A PAC, convém ressaltar, é financiada à custa de um importante desequilíbrio do orçamento da União Européia, desfavorável em especial à Alemanha. ${ }^{19}$ No capítulo agrícola, a França é a principal beneficiada. ${ }^{20}$ Isso explica o porquê da defesa incansável, da parte de seguidos governos franceses, do chamado modelo exportador e "produtivista" da PAC, que passou a ser abertamente criticado por ministros de países como Alemanha ou Dinamarca depois da aparição das crises da síndrome da "vaca louca" e da febre aftosa. Hoje, ganham volume as vozes favoráveis à substituição das políticas de manutenção artificial de preços e de subsídios às exportações pela ajuda direta aos produtores que garantirem a qualidade dos alimentos, a preservação do meio ambiente e da paisagem rural. ${ }^{21}$

Para os países do Mercosul, uma conseqüência direta desta impossibilidade de influir de maneira satisfatória nos esquemas de subsídios agrícolas mantidos pela União Européia é a posição cautelosa por eles assumida nas negociações. Como é pouco provável que a PAC venha a ser desmantelada - e certamente não o será pelo menos até 2006, frente aos compromissos assumidos na cúpula de Berlim -, os governos do Cone Sul têm pela frente um obstáculo, por ora, intransponível.

Única solução plausível para o impasse seria o avanço do dossiê agrícola na Organização Mundial de Comércio (OMC). Tema pendente desde o fim da Rodada Uruguai, em 1994, ele deveria obrigatoriamente ser tratado nas negociações agendadas para o ano 1999. Ora, essa alternativa, frente ao fracasso do lançamento 
da "Rodada do Milênio" em Seattle e às perspectivas pouco alentadoras de que ela será retomada no encontro de Doha, a ser realizado em novembro de 2001, mantém nebuloso o horizonte das negociações entre União Européia e Mercosul. ${ }^{22}$

\section{A proposta européia}

Enquanto as pespectivas multilaterais não anunciam avanços claros na liberalização do setor agrícola mundial, o máximo que os negociadores dos países do Mercosul podem fazer é procurar obter concessões nas próximas reuniões do Comitê de Negociações, quando as ofertas de cada lado serão confrontadas. Hoje, tanto da parte da União Européia como do Mercosul, elas foram ou ainda estão sendo estruturadas de maneira semelhante. Ambas contêm um conjunto "ofensivo" e outro "defensivo" de propostas. ${ }^{23}$

O primeiro reúne os setores nos quais cada bloco está interessado em ganhar mais mercado para suas exportações ou mais abertura e garantias para a realização de investimentos. O capítulo defensivo é composto de produtos ou setores considerados "sensíveis", a serem protegidos em uma lista de exceções que lhes permitirá usufruir de algum tipo de proteção tarifária por um prazo máximo de dez anos, a contar do dia em que o acordo de livre comércio começar a valer.

Como prevêm as regras da Organização Mundial do Comércio (OMC), apenas cerca de no máximo $15 \%$ do volume total do intercâmbio bilateral poderá ser protegido por tais listas de exceções. A OMC também permite uma livre negociação entre as partes dos prazos de carência e da velocidade da atenuação tarifária para diferentes listas de produtos ou setores. Ou seja, certos produtos poderão ter suas tarifas baixadas para zero nos primeiros anos do acordo, enquanto outros, considerados "sensíveis", poderiam manter proteção tarifária por prazos mais longos.

A proposta apresentada pela Comissão Européia por ocasião da quinta reunião do Comitê de Negociações Comerciais em Montevidéu, em julho de 2001, não poderia deixar de tratar da liberalização do setor agrícola, principal reivindicação do Brasil e de seus parceiros, Argentina, Paraguai e Uruguai. Segundo seus autores, ela prevê o fim de $90 \%$ dos obstáculos tarifários hoje impostos aos produtos agropecuários do Mercosul.

A proposta da União Européia para a liberalização de seu setor agrícola é dividida em seis grupos. ${ }^{24} \mathrm{O}$ primeiro reúne os produtos que poderiam ser importados do Mercosul com isenção total de tarifas já a partir da data de entrada em vigor do acordo de liberalização comercial: frutas tropicais frescas, maçãs e peras (entre os meses de abril e julho), laranjas e limões (de maio a outubro), óleos vegetais (exceto azeite de oliva) e algumas essências.

O segundo grupo, com prazo de quatro anos para zerar a tarifa, inclui flores, plantas, cebola, alho, uvas, ameixas, maçãs e pêras (de janeiro a março), 
melões, morangos, figos, frutas secas, preparados de carne de peru, carne de cavalo, óleos de milho, girassol e de palmeira. O terceiro grupo, com prazo de sete anos, inclui sucos de frutas, carne processada, miúdos, folhas de salada, laranjas (importadas em abril), frutas e vegetais processados (tomates, castanhas e azeitonas). Contariam com um prazo de dez anos de carência uma quarta lista incluindo mel, carne de porco, carnes enlatadas, suco de laranja congelado e suco de maçã. A liberalização do setor de bebidas alcoólicas, segundo a proposta européia, dependeria de um acordo de reconhecimento de denominações de origem; como é o caso, por exemplo, do Porto, da Champagne e do Cognac.

$\mathrm{Na}$ lista dos produtos considerados "sensíveis" pelos europeus, e que por isso poderiam continuar beneficiando-se de barreiras tarifárias: carne, frangos, tabaco, açúcar, cereais, arroz, óleo de oliva, laticínios e frutas processadas (geléias e compotas). Segundo os cálculos da Comissão Européia, esse sexto grupo representa apenas 10\% (900 milhões de euros) do comércio entre o Mercosul e a $\mathrm{UE}$, o que torna a proposta compatível com as regras da OMC.

Ela não leva em conta, por outro lado, o potencial de crescimento das importações de alguns destes produtos pelo mercado europeu. No caso do Brasil, o interesse em um acordo com a União Européia recai exatamente na possibilidade de aumentar as exportações de pelo menos quatro destes produtos - carnes, tabaco, açúcar e frangos -, hoje submetidos a toda sorte de barreiras tarifárias e nãotarifárias (como cotas e regras fitosanitárias). ${ }^{25}$

Além disso, a proposta da Comissão em momento algum toca na questão das distorções dos preços mundiais das "commodities" agrícolas provocadas pelas políticas de manutenção de preços e de subsídios à exportação oferecidos aos produtores europeus por meio da PAC. A idéia do governo brasileiro de calcular todos os tipos de subvenções e barreiras não-tarifárias em barreiras tarifárias, para facilitar e clarear as negociações, dificilmente receberá boa acolhida por parte da União Européia. A alternativa será a de tentar avançar estes temas na Organização Mundial do Comércio, o que não deixa de ir ao encontro da preferência nutrida na diplomacia brasileira pelas negociações multilaterais.

Se pouco pode oferecer em relação às políticas de subsídios à $\mathrm{PAC}$, nem por isso a Comissão Européia deixou de apresentar uma lista "ofensiva" ambiciosa para os setores de bens manufaturados, serviços, investimentos e compras governamentais. ${ }^{26}$ Para o setor industrial, como no caso da agricultura, separaram os produtos em quatro grupos. O primeiro, que teria suas tarifas zeradas a partir da entrada em vigor do acordo de liberalização comercial, inclui papel, madeira, fibras têxteis, couro, jóias e certos equipamentos. O segundo, com prazo de quatro anos, é composto por instrumentos ópticos, cerâmicas, aparelhos domésticos, aços e pelos equipamentos não incluídos na primeira lista. O terceiro, com prazo de sete anos, abarcará veículos, autopeças, calçados, aparelhos e produtos químicos. $\mathrm{O}$ quarto incluiria todos os demais produtos. 
Para o setor de serviços, a União Européia propõe a total liberalização do setor (com exceção dos produtos audiovisuais) e a remoção de todos os obstáculos ao comércio em áreas como transporte marítimo internacional, serviços financeiros e telecomunicações. Além disso, querem eliminar todos os obstáculos ainda existentes para a obtenção do controle acionário das empresas privatizadas no Brasil que já adquiriram participação.

No capítulo das compras governamentais, a Comissão Européia quer que as empresas de ambas as regiões possam competir em pé de igualdade no fornecimento de equipamentos e serviços para governos centrais, regionais ou municipais, incluindo licitações de empresas públicas. Por isso, pede um acordo sobre garantias de transparência, competição e não-discriminação contra empresas estrangeiras em licitações governamentais.

Finalmente, a União Européia demanda ainda a liberalização da pesca. O setor também foi dividido em quatro grupos. O primeiro, cujas tarifas baixariam a zero a partir da entrada em vigor do acordo, beneficiaria as importações de atum e salmão oriundos dos países do Mercosul. Camarões teriam carência de quatro anos, congelados de sete anos. A livre entrada de todos os outros tipos de pescados ficaria condicionada à abertura das zonas marítimas do Mercosul às frotas pesqueiras européias.

\section{O nó agrícola}

O desafio colocado pelo setor agrícola para as negociações de um acordo entre o Mercosul e a União Européia ficou explícito, como vimos acima, durante a realização da "fotografia" do comércio bi-regional ao longo de 1998. Por terem custos de produção mais baixos, os produtores agrícolas do Brasil e da Argentina foram considerados "altamente competitivos" a ponto de ameaçar até mesmo a existência da política agrícola comum européia (PAC).

Para sobreviver ao desafio de uma área de livre comércio com o Mercosul, a PAC precisaria receber uma injeção anual de recursos, estimada naquela ocasião, entre 5,3 bilhões a 14,3 bilhões de euros. Eles seriam necessários para sustentar os preços garantidos aos produtores, por exemplo, de açúcar (196\% mais caro na Europa que no Mercosul), milho (119\% mais caro) ou arroz (267\% mais caro).

Segundo o levantamento da Comissão Européia, entre os produtos íncluídos nos $14 \%$ do comércio considerado "sensível", encontravam-se cereais, aves, carne de porco, frutas, vegetais, laticínios e carne. Sobre este último item, o estudo da Comissão Européia apontava: "Assim que as tarifas caírem todos os tipos de carnes estarão habilitadas a entrar no mercado da UE, uma vez que a carne no Mercosul é produzida a preços muito competitivos e por isso a produção seria facilmente aumentada". ${ }^{27}$ 
O relatório ressaltava, ainda, que os preços da carne praticados pela União Européia eram, em 1998, 96\% superiores aos praticados no Mercosul, e lembrava que o rebanho do Mercosul, com 240 milhões de cabeças, era muito maior que o europeu, com 85 milhões de cabeças. E alertava para o fato de que "um sistema extensivo de produção é favorecido pela quase ilimitada disponibilidade de terra". ${ }^{28}$

A competitividade da agricultura dos países do Mercosul pode ainda ser comprovada pelos números do comércio com a União Européia. Em 1999, as exportações agrícolas do Mercosul para o mercado europeu, apesar das restrições e da PAC, somaram 10 bilhões de euros. No sentido inverso, as importações foram de apenas 858 milhões de euros, resultando em um superávit setorial de 9,18 bilhões de euros para os países do bloco sul-americano (ainda assim, o Mercosul apresentou um déficit de 2,9 bilhões de euros no conjunto da balança comercial). ${ }^{29}$

Tais "vantagens comparativas", portanto, só poderiam incentivar - seja em 1998 ou no presente - os representantes do Mercosul a buscarem um maior acesso ao mercado da União Européia para os produtos de sua agricultura. A Comissão, por sua vez, consciente da necessidade de oferecer algo de "substancioso" para os países do Mercosul no setor agrícola, para evitar um fracasso das negociações, conseguiu articular nos meses anteriores à reunião de Montevidéu uma proposta de redução tarifária com o aval dos comissários Pascal Lamy e Franz Fischler - do Comércio exterior e da Agricultura, respectivamente. Por outro lado, os próprios negociadores europeus têm as mãos atadas, e admitem que a Comissão Européia hoje pouco pode fazer em relação aos subsídios da PAC.

\section{Conclusão}

A realidade é que apenas as próprias conjunturas internas da União Européia poderão provocar mudanças na política agrícola e, então, facilitar as negociações com o Mercosul. Após realizarem uma reforma superficial da PAC em 1999, durante a Cúpula de Berlim, os líderes europeus marcaram a próxima reforma para 2006. Porém, agendaram então uma pequena revisão, ou “mid-term review”, para o período entre 2002 e 2003.

Até alguns meses atrás, pouco acreditava-se que essa nova discussão poderia resultar em algo de concreto. Entretanto, as crises da "vaca louca" e da febre aftosa mudaram o cenário. Pela primeira vez nos 40 anos de política agrícola, reações dos consumidores, que fizeram a venda de carne cair por volta de $30 \%$ no continente, levaram os governos a questionar se a PAC está no rumo certo.

Desde então, o governo da Alemanha, país responsável pelo financiamento de mais da metade do orçamento comunitário, passou a apoiar uma mudança radical da PAC, pedindo o fim de seu modelo "produtivista". Outros países, como a Suécia ou a Dinamarca, também gostariam de ver a Comissão financiando uma produção 
de menor quantidade e maior qualidade; adotando, por exemplo, medidas de apoio aos pequenos produtores ou à agricultura orgânica. Tal idéia foi, e tem sido, tema de discordâncias entre a ministra alemã da Agricultura, Renate Kuenast, e seu colega francês, Jean Glavany - a ponto deste último afirmar que a França poderia vir a criar seu próprio fundo nacional de ajuda aos agricultores, caso a PAC deixe de atender os interesses de seu país. ${ }^{30}$

Caso tal debate seja aprofundado nos próximos meses, poderia-se esperar que durante a revisão da política agrícola, que acontecerá entre 2002 e 2003, sejam rediscutidos os tipos de apoio oferecidos pela União Européia a seus agricultores. As políticas de manutenção artificial de preços e de subsídios às exportações estão sob pressão. Um estudo sobre a reforma da PAC encomendado pelo comissário Romano Prodi prevê que haverá maior pressão interna para reorientar os fundos da Comissão para políticas menos distorsivas do comércio mundial, como desenvolvimento rural, garantia de rendimento mínimo aos agricultores e proteção do meio ambiente.

Porém, uma reorientação a curto prazo da PAC depende ainda de outros três fatores. Primeiro, das negociações do tema agrícola na Organização Mundial do Comércio, que entram em sua fase decisiva a partir de 2002. Segundo, das eleições na Alemanha e na França, que acontecerão também no primeiro semestre do próximo ano. No caso francês, o enfraquecimento da candidatura de Jacques Chirac, um tradicional defensor dos poderosos lobbies agrícolas de seu país, poderia ser determinante para se medir qual será o grau de profundidade do "mid-term review" que a União Européia realizará entre 2002 e 2003.

Em terceiro lugar, uma ainda incerta reforma da PAC dependerá de como a atual União Européia pretende absorver a produção agrícola dos países candidatos a aderir ao bloco, como a Polônia, a República Tcheca ou a Hungria. O processo de alargamento, como já vimos, cria uma dificuldade adicional às negociações com o Mercosul, pois os produtores europeus temem uma dupla exposição à concorrência vinda da Europa do Leste e da América do Sul.

Por isso, é razoável esperar que o nó agrícola somente será desembaraçado na Organização Mundial do Comércio, onde todas estas questões, inclusive as reivindicações dos exportadores agrícolas, como o Brasil e a Argentina, podem ser tratadas de uma só vez. No caso de todos esses fatores convergirem de maneira positiva, e caso mantenha-se a atual indignação dos consumidores europeus com o atual modelo "produtivista", poderíamos, então, esperar um entendimento sobre as grandes linhas da reforma da PAC, para os dois próximos anos, que fosse ao encontro das expectativas nutridas pelos países do Mercosul em relação às negociações em curso com a União Européia.

Outubro de 2001-10-22 


\section{Notas}

1 Ver "A alternativa que vem da Europa”, República, n 56, junho de 2001, pág. 38.

2 Ver “Acordo com UE terá lista de setores sensíveis", in Valor Econômico, 14/09/2001.

3 EUROSTAT, Intra and Extra-EU Trade, CD-ROM, Office for official publications of European Communities. Luxemburgo, 1999.

4 DG TRADE, janeiro de 2001, in www.europa.eu.int.

5 Ver "Iniciativa européia para as Américas", in Correio Braziliense, 02/11/2000.

$6 \quad$ Ver “A alternativa que vem da Europa”, República, n 56, junho de 2001, pág. 36.

7 Sobre as linhas gerais da política externa brasileira, ver CERVO (1994) e SARAIVA (1997).

8 Sobre a história e os princípios norteadores do processo de integração do Mercosul, ver ARAÚJO e FLORÊNCIO (1995).

9 Ver LIMA (1999).

10 "EU/Agriculture Council; Majority of agriculture ministers express concerns and reluctance regarding plans for a free trade area with Mercosur", in Agence Europe, boletim n ${ }^{\circ} 7268,23 / 07 /$ 1998.

11 Idem idem.

12 First Meeting of the European Union - Mercosur Biregional Negotiations Committee. Draft conclusions. Mimeo. Buenos Aires, 07/04/2000.

13 Ver "Entrevista: José Alfredo Graça Lima", Correio Braziliense, 25/03/2001

14 Tome-se como exemplo a seguinte declaração de Luiz Fernando Furlan, presidente do conselho de administração da Sadia e vice-presidente da Federação das Indústrias do Estado de São Paulo (Fiesp): "Temos muito mais chance de caminhar com a UE do que com a Alca; não vejo os americanos dando prioridade ao acordo hemisférico; com os ataques terroristas vão olhar para o próprio umbigo; eles têm dificuldade em despasteurizar a América Latina". A citação foi encontrada no artigo "Acordo com UE terá lista de setores sensíveis", in Valor Econômico, 14/ $09 / 2001$.

15 Ver "Acordos com EUA afetam Mercosul”, in Gazeta Mercantil, 11/05/2001.

16 Ver "Acordo com UE terá lista de setores sensíveis", in Valor Econômico, 14/09/2001.

17 Análise Comparativa dos Ganhos de Integração: Alca e União Européia, Fundação Getúlio Vargas, mimeo, 1998.

18 A chamada "Agenda 2000", adotada por ocasião da Cúpula de Berlim, fixou o horizonte da ajuda comunitária aos produtores agrícolas da União Européia a uma média anual de 40,5 bilhões de euros até 2006 , cifra a qual se deve somar outros 14 bilhões de euros destinados ao desenvolvimento rural e às medidas fitosanitárias e veterinárias. Em 2002, os subsídios atingirão seu valor máximo, 43,9 bilhões de euros. A partir daí, baixarão progressivamente, até atingir 41,6 bilhões de euros em 2006. Ver LOYAT e PETIT, 1999.

19 Em 1997, a contribuição da Alemanha ao orçamento comunitário era de 21,2 bilhões de euros $(28,2 \%)$, resultando para o país um déficit de 10,9 bilhões de euros. A França, segundo maior contribuinte, pagou no mesmo ano 13,1 bilhões de euros (17,5\%), com um déficit de apenas 781 milhões de euros. Tais disparidades levaram o governo alemão a acionar uma conclusão do Conselho Europeu de Fontainebleau, de junho de 1984, prevendo o direito a uma correção para países com obrigações orçamentárias excessivas. (LOYAT e PETIT, 1999).

20 Em 1997 a França recebeu 9,1 bilhões de euros em ajuda agrícola, enquanto a Alemanha recebeu apenas 5,7 bilhões de euros. (LOYAT e PETIT, 1999)

21 Ver "Crise du modèle agroalimentaire", in Le Monde - Dossiers \& Documents, n²99, junho de 2001.

22 Ver "Negociadores tentam salvar nova rodada comercial internacional", in O Estado de S. Paulo, 28/07/2001. O artigo cita negociadores latino-americanos e europeus junto à OMC, em Genebra, afirmando que as perspectivas para um acordo sobre o tema agrícola hoje são mais sombrias do que às vésperas da reunião, fracassada, de Seattle. 
23 Ver “Acordo com UE terá lista de setores sensíveis", in Valor Econômico, 14/09/2001.

24 As informações detalhadas sobre a proposta européia constam do documento EU/Mercosur Negotiations: Presentation of the EU tariff offer and negotiating text for free circulation of goods, services and government procurement. European Comission. Brussels, 5/07/2001. O levantamento mais completo sobre as barreiras enfrentadas pelos produtos brasileiros na UE é A Política Comercial da União Européia e as barreiras às Exportações Brasileiros, produzido e atualizado pela Missão do Brasil junto às Comunidades Européias, mimeo, 2000.

26 EU/Mercosur Negotiations: Presentation of the EU tariff offer and negotiating text for free circulation of goods, services and government procurement. European Comission. Brussels, 5/ $07 / 2001$.

27 "Mercosur FTA could add 25\% to cost of CAP", in Agra Europe, boletim n 1807, 17/07/1998.

28 Idem idem.

29 DG TRADE, janeiro de 2001, in www.europa.eu.int.

30 "France and Germany differ on future of EU farming", in Reuters Agency News, 16/02/2001.

\section{Bibliografia}

ALMEIDA, Paulo Roberto de. Mercosul e União Européia: Vidas Paralelas?, in Boletim de Integração Latino-Americana, $\mathrm{n}^{\circ}$ 14, julho-setembro, 1994.

ARAÚJO, E. H. F. e FLORÊNCIO, S. A. L. Mercosul Hoje. São Paulo, Alfa-Ômega, 1995.

CERVO, A. L. (org.). O Desafio Internacional. A Política Exterior do Brasil de 1930 a nossos dias. Brasília, Coleção Relações Internacionais, Editora da UnB, 1994.

CERVO, A. L. e RAPOPORT, M. História do Cone Sul. Rio de Janeiro, Revan; Brasília, EdunB, 1998.

EUROSTAT, Intra and Extra-EU Trade, CD-ROM, Office for official publications of European Communities. Luxemburgo, 2000.

GIORDANO, P., VALLADÃO, A. e DURAND, M. (org.). Vers un accord entre l'Europe et le Mercosur. Paris, Presses de Sciences Po, 2001.

GRATIUS, Susanne. El Mercosur y la Comunidad Europea: una guia para la investigación. Madri, Irela, 1993.

IRELA, La Unión Europea y el Grupo de Río: la agenda birregional, documento de base. Madri, 1998.

. Closer European Union Links with Eastern Europe: Implications for Latin America. Madri, 1997.

. Mercosur and the European Union: Dynamics and Prospects of a Developing Association. Madri, 1999.

. Preparando la Asociación UE-MERCOSUR: Beneficicios y obstáculos. Madri, 1998.

. Un desafio al triángulo atlántico? Contexto y agenda de una cumbre EU-América Latina, Madri, 1997.

. Unión Europea-Mercosur: el largo camino haciala liberalización comercial. Madri, 1998.

LAVAGNA, R. Los Nuevos Horizontes de la Integración ante los Desafíos de la Globalización y la Ronda del Milenio, in Escenarios Estratégicos de la Integración en el Umbral del Siglo XXI: Perspectivas Americanas y Europeas. Brasília, mimeo, Cefir, 1998.

LIMA, José Alfredo Graça. O processo de associação Mercosul-UE, in Política Externa. São Paulo. Vol. 8, n 1, junho/julho/agosto de 1999.

LOYAT, J. e PETIT, Y. La politique agricole commune. Paris. La documentation française, 1999.

NEVES, Luiz Augusto de Castro. A Cimeira do Rio de Janeiro, in Política Externa. São Paulo. Vol. 8, $\mathrm{n}^{\circ} 2$, setembro/outubro/novembro de 1999. 
RAPOPORT, M., e Andrés, M. La Comunidad Europea y el Mercosur-Una evaluación comparada. Buenos Aires, Fihes/ Fundação Konrad Adenauer, 1993.

RODRIGUES, R., LOPES, M. R. As negociações do Brasil e o Mercosul com a União Européia, in Política Externa. São Paulo. Vol. 7, n 4, março de 1999.

SARAIVA, J. F. S. (org.). Relações Internacionais Contemporâneas - Da Construção do mundo liberal à globalização - de 1815 a nossos dias. Brasília, Paralelo 15, 1997.

\section{Documentos}

First Meeting of the European Union-Mercosur Biregional Negotiations Committee. Draft conclusions. Mimeo. Buenos Aires, 7/04/2000.

Second Meeting of the European Union - Chile Negotiations Committe. Final conclusions. Mimeo. Brussels, 20-23/06/2000.

Third Meeting of the European Union - Mercosur Biregional Negotiations Committee. Final Conclusions. Mimeo. Brasília, 7-10/11/2000.

Fourth Meeting of the European Union - Mercosur Biregional Negotiations Committee. Final conclusions. Mimeo. Brussels, 19-22/03/2001.

A Política Comercial da União Européia e as barreiras às Exportações Brasileiros. Missão do Brasil junto às Comunidades Européias, mimeo, 2000.

EU/Mercosur Negotiations: Presentation of the EU tariff offer and negotiating text for free circulation of goods, services and government procurement. European Comission. Brussels, 5/07/2001.

\section{Resumo}

O artigo procura demonstrar que a recente apresentação, por parte da Comissão Européia, de uma proposta de redução tarifária para as exportações do Mercosul não deve ser interpretada como um sinal de que as negociações comerciais entre os dois blocos serão mais fáceis do que a criação da Área de Livre Comércio das Américas - uma vez que parecem poucas as probabilidades de que a União Européia venha a realizar uma profunda reforma de sua política agrícola comum (PAC) nos próximos anos.

\section{Abstract}

The article seeks to show that the proposal recently presented by the European Comission, promissing the decreasing of trade barriers for Mercosur's agriculture exports to European markets, should not be incautiously interpreted as a sign that a trade agreement between them will be easier to achieve than the creation of the Free Trade Area of the Americas (FTAA). It still remains uncertain that the European Union will accomplish a deep reform of its common agricultural police (CAP).

Palavras chaves: Mercosul. União Européia. Comércio. Agricultura. OMC. Key-words: Mercosur. European Union. Trade. Agriculture. WTO. 